\title{
Soil Restoration: Drought Resistance, Soil Health Improvement, Toxin Sequestration and Worms
}

\author{
Leonard Sonnenschein ${ }^{1 *}$, Kenneth Masuki ${ }^{2}$, Osia Odula ${ }^{3}$ and Etyang Tiberious Brian ${ }^{4}$ \\ ${ }^{1}$ International Director of Agriculture, President, Conservation for the Oceans Foundation, Chief Science Officer, Salvation Farming Solutions, LLC, 9858 Clint \\ Moore Road, Suite C111-177, Boca Raton, Florida 33946. USA. \\ ${ }^{2}$ Research and Development Manager, Salvation Farming Solutions, Department of Horticulture and Food Security, Jomo Kenyatta University of Agriculture and \\ Technology, Kenya \\ ${ }^{3}$ Training and Outreach Officer, Salvation Farming Solutions, Department of Horticulture and Food Security, Jomo Kenyatta University of Agriculture and \\ Technology, Kenya \\ ${ }^{4}$ Managing Director Salvation Farming Solutions -Africa and Co-Founder eNSPIRE Africa
}

*Corresponding author: Leonard Sonnenschein, International Director of Agriculture, President, Conservation for the Oceans Foundation, Chief Science Officer, Salvation Farming Solutions, LLC, 9858 Clint Moore Road, Suite C111-177, Boca Raton, Florida 33946. USA.

Received Date: November 09, 2019

Published Date: November 14, 2019

\begin{abstract}
Unprecedented population growth is being experienced globally and there is low food production that is unable to meet the demand due to population growth. The Agricultural Production System since the 1950 has become heavily dependent upon chemical inputs and the land and sea have been significantly affected by this buildup of chemicals including the rise of dead zones around the world. This opinion article points to the harsh realities of this overworked system and how it affects us all. There is a conclusion about what the future holds and where the Agriculture Industry needs to go towards greater sustainability. Agriculture contaminants from previous years affect soil health and the future sustainability of crop production not to mention the deleterious effects on streams, lakes and ocean areas that are being polluted and species dying to support the faster growing. Plants are currently not producing to their optimal potential to provide for adequate global food security. It is our opinion that soil health is the key to the success of improving crop production. Recent research will show the overall effects on the very culture of soil health, on runoff effects on cyanobacteria, devastation of biological systems both in the soil and water that support life and decontaminate the downstream pollutants of phosphorous and nitrogen that come from the agriculture inputs and the lack of efficiently reining in the effects of the unused products that wash away. New products are contemplated to decrease the use of fertilizer, increase the growth of plants, increase nutritional density of the foods being raised and increase product awareness at all levels of the food chain to help drive better choices about what we eat and how it affects ecosystems all over the world. Also, there are bright spots in how to use trees to help soil restoration.
\end{abstract}

Keywords: Soil restoration; Regenerative agriculture; Ecosystem health; Cyanobacteria; Phosphate reduction; Nitrogen reduction; Agriculture runoff; Tree productivity and agriculture; Water health; Maize

\section{Introduction}

Land and water systems are on the verge of a collapse due to various failed schemes [1]. The ecological impact on water/land use along with dilutive residues of pesticides, herbicides, fertilizers, and over-use of soil and waterways have led to an inability for land and water systems to be sustainably managed.

The effects of climate change have further marginalized Land and Sea productivity due to change in soil and water conditions and relative cropping/water use equations [2].

Effluents from farm fields are toxifying streams and residues are being built up in adjoined waterways in the form of new eutrophic zones (dead zones); often the result of fertilizers being used to heavily increase agricultural production without consideration of the land and water ecosystem resource impact.

\section{Discussion}

The effects of agricultural runoff: nitrogen and phosphates

The agricultural sector is primarily responsible for excess nitrogen in the form of ammonia, nitrite and nitrate, phosphorus, pesticides, and pathogen pollution of water bodies in agricultural zones. Nitrogen and phosphorous are causal to eutrophication in 
water bodies and affecting aquatic life [3]. In maize production region of Uasin Gishu County, which is Kenya's food basket, Ontumbi et al. [4] established that River Sosiani was stressed by nutrients (nitrates and phosphorous) originating from agricultural activities resulting in loss of biodiversity [5] and algal blooms. In Zimbabwe, Nyamangara et al. [6] reported that anthropogenic activities within the Upper Manyame Catchment Area (UMCA) were the major sources of nitrate and phosphate pollution in the three rivers and were a serious threat to the environmental sustainability of the rivers and lakes downstream. A study conducted in central Tanzania region of Singida on soils and water resources revealed that nitrate levels in water in the selected locations in Singida Urban District ranges from $105 \mathrm{mg} / \mathrm{L}$ to $476 \mathrm{mg} / \mathrm{L}$, the values which are above the maximum recommended standard of 50 $\mathrm{mg} / \mathrm{L}$ as described by WHO [7] and of $20 \mathrm{mg} / \mathrm{L}$ as per TBS [8], thus long term consumption by human beings and animals without treatment to reduce levels of nitrates may result in health problems in human and animals in the area. High levels of nitrates in water in the study area resulted from human activities particularly waste disposal, the use of natural agricultural inputs (animal manure) and crop residuals [9]. Concentration of nitrate in groundwater in many parts of Tanzania is above the background level of $10 \mathrm{mg} / \mathrm{l}$ and in some places exceeds WHO maximum recommended levels for drinking water. Highest values were observed in urban areas of Dar es Salaam, Dodoma and Tanga where the concentration of nitrate in some aquifers was higher than $400 \mathrm{mg} / \mathrm{l}$. Generally, in urban areas, concentration of nitrate in groundwater samples decreased as one moved from densely populated areas to sparsely populated areas probably due to decreasing density of sanitation facilities. In rural settings, elevated nitrate concentration in the groundwater probably was contributed by excessive use of fertilizers (inorganic fertilizers and animal manure) [10].

\section{Restoring plant health}

Plant health can be affected by lack of either or both macro and micronutrients, disease and pests' infestations and physiological disorders. Nutrient deficiencies can be as a result of lack or excess of nitrogen, potassium, phosphorous, magnesium or boron, copper, zinc etc. Most croplands of Tanzania have low fertility and nitrogen is the most limiting nutrient [11]. Soil phosphorus availability is commonly low. There are occasional indications of localized $\mathrm{Cu}, \mathrm{Zn}$ and Mn deficiencies [12].

- Nitrogen deficiency: Low or high pH soils make the problem worse as do sandy and light soils because leaching takes place with the nutrients draining away through the soil too easily.

- $\quad$ Phosphorous (P): Acidic and very alkaline soils worsen the plant health. Crops with poorly developed root systems struggle without enough phosphorous.

- $\quad$ Potassium (K): Drought conditions and high rainfall or heavy irrigation are equally problematic when the balances of potassium are important for healthy green foliage and ensures optimal root growth.

- Magnesium (Mg): Magnesium contributes towards healthy plant development, aids with maturation process to bring forward the harvest and improves yield.

- $\quad$ Calcium (Ca): Calcium is important for healthy foliage and contributes to improved quality of grain and increased yields.

- Sulphur (S): S contributes to green foliage, healthy growth of the maize plant and contributes to an effective uptake of nitrogen by the crop.

- $\quad$ Boron (B): B is particularly important for cob and kernel development.

- Zinc (Zn): Zinc is important for good plant development early in the season and helps improve yields as well as speeds up the maturation of the plant to bring the harvest date forward.

According to Sonnenschein and Etyang [13], maize plants respond to improved soil health visually noted with increased natural moisture retention with soil becoming darker, having more worms per cubic meter of soil also indicating greater soil microbial life, with the stalks and roots being taller and thicker thus resulting in higher plant biomass in addition to doubling the cob production, pest and pathogen-free with far greater nutritional density when compared to the control plants. Clearly, micronutrients play a very important role in the life cycle of a plant.

\section{Restoring tree productivity}

Many smallholder farmers in Sub-Saharan Africa practice agroforestry. These systems have prevailed despite persistent attempts to introduce monoculture production of annual crops, which have been much less successful in Africa than elsewhere. This calls for use of low-cost option of agroforestry to replenish the lost soil nutrients. Agroforestry has been known to enhance soil fertility, improve farm income, protect water catchments, restore landscapes, conserve biodiversity and resilience against the impacts of climate change in sub Saharan Africa [14]. Soil carbon, in the form of organic matter is an indicator of soil biological activity and health. The use of diverse tree species in agroforestry systems represents alternative forms of increasing soil fertility and sustaining agricultural production [15]. Agroforestry practices have been promoted for decades both in the tropics and temperate regions of the world for their perceived benefits of not only improving soil quality, but also providing other ecosystem services [16]. Many of the environmental benefits and ecosystem services expected from agroforestry would not be materialized unless these practices improved the capacity of soils to be productive and healthy over the long term. Incorporation of trees in agroforestry enhances the Soil Organic Matter (OM) by adding litter both above and belowground. Soil OM is the energy source of soil organisms and influences both soil biodiversity and associated soil biological 
functions. As a result, Soil Organic Carbon (SOC) is one of the important indicators used in assessing soil health [17].

\section{Agriculture practices affect fisheries productivity, coral reef restoration and water health}

Lake Victoria in East Africa has been a recipient of both agricultural and urban waste resulting in an increase in phytoplankton, cyanobacteria, water hyacinth, and eradication of endemic cichlid fishes [3]. Mangroves at the Kenyan coast are under persistent pressure from human activities such as fish farming, manufacturing of salt, agriculture production and housing construction. Mangroves help in siltation of coral reefs and contributes to organic matter and nutrients productivity of the coastal ecosystems [18].

Cyanobacteria (blue-green algae) are photosynthetic and chemosynthetic bacteria that under favorable environmental conditions produce toxic secondary metabolites (cyanotoxins) which are harmful to the environment, including humans. Harmful cyanobacteria, or CyanoHABs, are now a problem of global environmental concern and efforts are being taken to prevent, predict, minimizes, and suppress their occurrences [19]. In nearby Lake Victoria, blooms of cyanobacteria have been observed since 1980 which are associated with massive fish kills [12]. Studies by Kihwele et al., [20] and others in the United Republic of Tanzania have demonstrated the occurrence of toxin producingcyanobacteria in specific regions.

Other indicator species such as Flamingos have shown mortality from the presence of these harmful algal blooms in Tanzania is the mass fatality of Lesser Flamingos in saline lakes in Arusha and Manyara Region [21].

In order to investigate the potential for microcystin (MC) production by cyanobacteria in the Mwanza Gulf (Lake Victoria, Tanzania), nutrients, phytoplankton and microcyst ins were sampled inshore (3m depth) and offshore (18m depth) from May to August 2002. Significant differences in soluble reactive phosphorus (SRP) and nitrate concentrations between offshore and inshore indicated eutrophication via terrestrial run-off.

\section{Conclusion}

Massive chemical agricultural inputs have changed soil health and downstream ecosystem vitality through depletion of micronutrients and undeniably have changed entire living macrocosms in soil and water. Regenerative Agriculture practices reinforce the microcosms in the soil for beneficial biochemical mechanisms to have positive land and downstream effects in restoring the balances to improve sustainable productivity. Recent advances in nature-based Regenerative Agriculture including Soil Treatments, Fertilizer Amendments, Seed Treatments and NatureBased Pesticides have been found to increase productivity and nutritional densities and detoxify the soils, increase natural soil health including worm presence, increase moisture availability, normalize $\mathrm{pH}$, alkalinity, decrease nitrogen and phosphorus, aid oxygenation and promote beneficial bacteria sustainably to further improve land and sea ecosystems with specific amendments to eliminate residual nitrates and phosphates to affect the cyanobacteria and blue-green algae issues found in many productive agricultural areas. The future must be to have increased agriculture production without the negative environmental consequences. We believe we are almost there.

\section{Acknowledgement}

Thanks to Dr. Charles R. Granger for being a great mentor.

\section{Conflict of Interest}

No conflict of interest.

\section{References}

1. SONNENSCHEIN L (2017) Linking the Land to the Sea Relationships: Building agricultural capacity, reducing pollution and restoring crucial nutrients for ecosystem recovery Marine Science 2017, Kuala Lumpur, Malaysia.

2. SONNENSCHEIN L (2014) Climate change affect physical \& biological properties significantly within ocean \& coastal areas and present information about understanding, financing, protecting \& restoring these natural areas integrating transparent communication, mitigation \& measurement practices. United Nations Climate Change Conference, UNFCC Lima, Peru December 1-12.

3. JUMA DW, WANG H, LI F (2014) Impacts of population growth and economic development on water quality of a lake: case study of Lake Victoria Kenya water. Environmental Science and Pollution Research 21: 5737-5746.

4. ONTUMBI G, OBANDO J, ONDIEKI C (2015) The influence of agricultural activities on the water quality of the river Sosiani in Uasin Gishu County, Kenya. International Journal of Research in Agricultural Sciences, 2(1).

5. RWAKAIKARA-SILVER MC, ISABIRYE BE, AKOL AM, NKWIINE C, OKWAKOL MJN, et al. (2010) Ecology \&Management of soil biodiversity in Mabira Forest, Uganda: an Inventory. Towards conservation and sustainable management of below ground biodiversity in Uganda. CSM-BGBD Report number 09-02. designed and printed by Makerere University Printery Kampala-Uganda.

6. NYAMANGARA J, JEKE N, RURINDA J (2013) Long-term nitrate and phosphate loading of river water in the Upper Manyame Catchment, Zimbabwe. Water SA 39: 637-642.

7. WHO (2007) Nitrate and nitrite in drinking water. Geneva, Switzerland, pp. 1-31.

8. TBS (2005) National Environmental Standards Compendium: Tanzania Bureau of Standards, Dar es Salaam, Tanzania, 10pp.

9. LWIZA LM (2016) Assessment of Nitrate Levels in Water and Soils for Agriculture and Human Utilization in Singida District, Tanzania. MSc Dissertation, Sokoine University of Agriculture. Morogoro, Tanzania.

10. ELISANTE E, MUZUKA ANN (2017) Appl Water Sci 7(1): 71-87.

11. MARANDU AET, MBOGONI JDJ, LEY GJ (2014) (Eds) Revised Fertilizer Recommendations for Maize and Rice in the Eastern, Southern Highlands and Lake Zones of Tanzania. Ministry of Agriculture, Food Security and Cooperatives, Department of Research and Development, Dar- es-Salaam, Tanzania.

12. NDLELA LL, OBERHOLSTER PJ, VAN WYK JH, CHENG PH (2016) An overview of cyanobacterial bloom occurrences and research in Africa over the last decade. Harmful Algae 60: 11-26.

13. SONNENSCHEIN L, ETYANG TB (2019) Dealing with the Sins of the Past and Work towards a Nature-Based Future: New Innovative Technologies for Sustainable Agriculture. World Journal of Agriculture and Soil Science 2(1): 1-7. 
14. MBOW C, VAN NOORDWIJK M, LUEDELING E, NEUFELDT H, MINANG PA, et al. (2014) Agroforestry solutions to address food security and climate change challenges in Africa. Current Opinion in Environmental Sustainability 6: 61-67.

15. HUGHES K, MORGAN S, BAYLIS K, ODUOL J, SMITH DUMONT E, et al. (2017) Assessing the Downstream Socioeconomic and Land Health Impacts of Agroforestry Promotion in Western Kenya.

16. JOSE S (2009) Agroforestry for ecosystem services and environmental benefits: an overview. Agrofor Syst 76(1): 1-10.

17. DOLLINGER J, JOSE S (2018) Agroforest Syst 92(2): 213.

18. ABUODHA P, KAIRO J (2001) Human-induced stresses on mangrove swamps along the Kenyan coast. Hydrobiologia 458(1-3): 255-265.
19. GATZ L (2018) Freshwater Harmful Algal Blooms: Causes, Challenges, and Policy Considerations.

20. KIHWELE ES, LUGOMELA C, HOWELL KM (2014) Temporal changes in the lesser flamingos population (Phoenicopterus minor) in relation to phytoplankton abundance in Lake Manyara, Tanzania. Open journal of ecology Tanzania. Open J Ecol 4: 145-161.

21. OFFORO N KIMAMBO, JABULANI R GUMBO, HECTOR CHIKOORE (2019) The occurrence of cyanobacteria blooms in freshwater ecosystems and their link with hydro-meteorological and environmental variations in Tanzania. Heliyon 5(3): e01312. 